\title{
A conservation assessment of the amphibians and reptiles of the Forêt d'Ambre Special Reserve, north Madagascar
}

\author{
Neil D’Cruze, Jörn Köhler', Michael Franzen" and \\ Frank Glaw"
}

\author{
Correspondence: \\ Neil D'Cruze \\ The World Society for the Protection of Animals \\ 89 Albert Embankment, London, WE1 7TP, United Kingdom \\ E-mail: cruzecontrol@gmail.com
}

\begin{abstract}
We surveyed the lowland rainforest of the Forêt d'Ambre Special Reserve in north Madagascar for amphibians and reptiles. We recorded a total of 20 amphibian and 39 reptile species via opportunistic searching and pitfall trapping in the first published survey to focus on this area. Consequently most of the species found were new records for the area. Approximately half of the species $(51 \%)$ were only found in relatively undisturbed areas of forest and $61 \%$ appear to be restricted to lowland rainforest below 900 m elevation. The most vulnerable elements of this herpetofauna are the three species that appear to be locally endemic to Forêt d'Ambre (according to the current knowledge): Boophis baetkei, Brookesia sp. nov., and Rhombophryne sp. nov. An additional 25 species are considered regional endemics, 14 species are threatened according to the 2007 Red List of Threatened Species and 15 species are listed on the CITES appendices. This paper contributes to the current understanding of Malagasy patterns of biodiversity by documenting the composition, geographical and ecological distribution of the herpetofauna found at this site. Despite its protected status, currently the Reserve is not being managed sufficiently as it is subject to numerous human-induced environmental problems resulting in habitat destruction and should therefore be considered a high conservation management priority. Herein, we provide conservation and development recommendations for this highly diverse site of herpetological importance. Furthermore, we provide an updated and revised species list of the amphibians and reptiles of Montagne d'Ambre National Park and a species list for the private Fontenay Nature Park.
\end{abstract}

\section{RÉSUMÉ}

Lors d'un inventaire des espèces d'amphibiens et de reptiles de la Réserve Spéciale de la Forêt d'Ambre au nord de Madagascar, nous avons recensés un total de 20 espèces d'amphibiens et de 39 espèces de reptiles par le biais d'échantillonnages directs et avec des trous-pièges "pitfall traps», constituant ainsi le premier résultat d'inventaire publié sur cette zone. De sorte que toutes les espèces répertoriées constituent de nouvelles données pour cette région. Environ une moitié des espèces (51\%) n'a été trouvée que dans des zones forestières peu perturbées et $61 \%$ se limitent à la forêt pluviale de basse altitude (altitude inférieure à $900 \mathrm{~m}$ ). Les éléments les plus vulnérables de cette herpétofaune sont les trois espèces qui semblent être localement endémiques, à savoir Boophis baetkei, Brookesia sp. nov. et Rhombophryne sp. nov. Par ailleurs, 25 autres espèces sont endémiques de la région, 14 espèces sont inscrites sur la liste rouge IUCN 2007 des espèces menacées et 15 sont inscrites dans les annexes de la CITES. Ce travail contribue à une meilleure compréhension des schémas de la biodiversité malgache en documentant la composition ainsi que la distribution géographique et écologique de l'herpétofaune recensée sur ce site. Malgré son statut de protection, la réserve est soumise à de nombreuses perturbations d'origine anthropique entrainant une destruction de I'habitat et devrait à ce titre être considérée comme une zone prioritaire en matière de conservation. Nous formulons des recommandations pour la conservation et le développement de ces sites qui présentent une diversité faunique importance. Nous fournissons également une liste mise à jour et révisée des amphibiens et des reptiles du Parc National de la Montagne d'Ambre, ainsi qu'une liste du parc privé 'Fontenay Nature Park'.

KEYWORDS: Amphibia; Conservation; Forêt d'Ambre; Madagascar; Montagne d'Ambre; Reptilia.

\section{INTRODUCTION}

The Forêt d'Ambre is an area of forest located at the foot of the Montagne d'Ambre mountain complex, which runs north-south at the extreme northern tip of Madagascar (Figure 1). Part of the subhumid bioclimatic zone originally defined by Cornet (1974) and further utilized by Schatz (2000), it is subject to marked seasonal variation, with a distinct and relatively long dry season followed by a wet season lasting from December to April. The annual precipitation of this location is higher than that received by the town Antsiranana, which has a mean of $980 \mathrm{~mm}$ (Nicoll and Langrand 1989), and is probably lower to that received at

I Jörn Köhler, Hessisches Landesmuseum Darmstadt, Department of Natural History - Zoology, Friedensplatz 1, 64283 Darmstadt, Germany

E-mail: j.koehler@hlmd.de

II Michael Franzen and Frank Glaw, Zoologische Staatssammlung München, Münchhausenstr. 21, 81247 München, Germany

E-mail: Michael.Franzen@zsm.mwn.de and Frank.Glaw@zsm.mwn.de 


\section{VOLUME 3 ISSUE 1

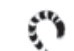 DECEMBER 2008 MADAGASCAR \%, CONSERVATION \& DEVELOPMENT}

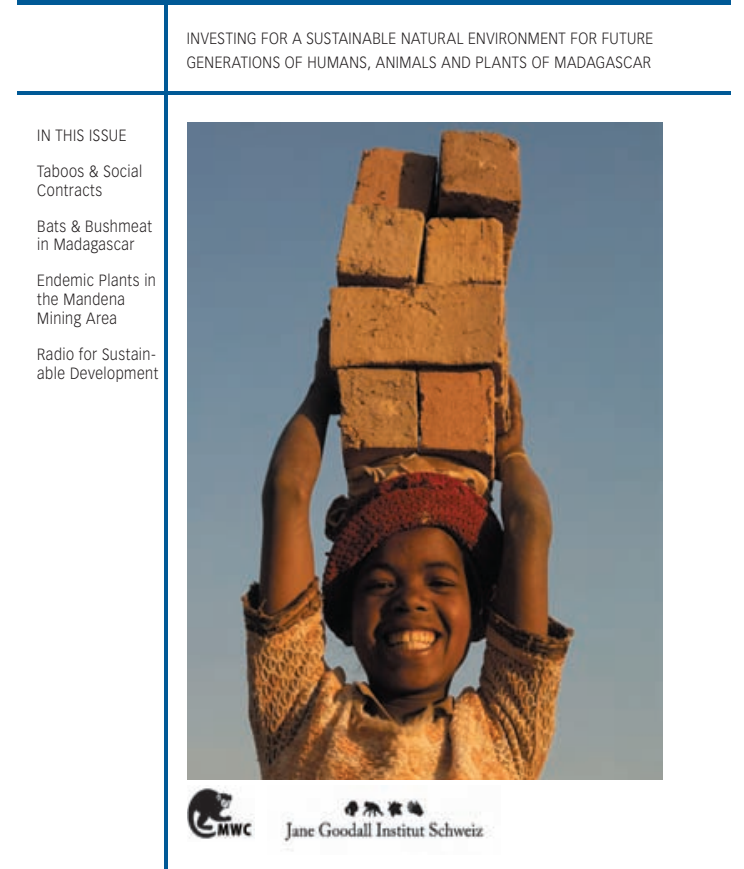

Madagascar Conservation \& Development is the journal of Madagascar Wildlife Conservation (MWC) and the Jane Goodall Institute (JGI Switzerland). It is produced in these institutions' own responsibility.

All the Issues and articles are freely available at http://www.mwc-info.net/en/services/journal.htm

Contact Journal MCD

info@journalmcd.net for general inquiries MCD funding@journalmcd.net for supporting the journal

Journal Madagascar Conservation \& Development Institute and Museum of Anthropology University of Zurich

Winterthurerstrasse 190

$\mathrm{CH}-8057$ Zurich, Switzerland

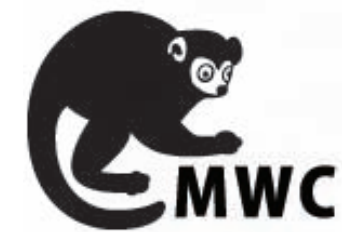

contact@mwc-info.net for general inquiries

Postfach 2701

CH-8021 Zürich, Switzerland

Logement 11, Cité Andohaniato Antananarivo 101, Madagascar

info@janegoodall.ch for general inquiries JGI

\section{$2 \pi$}

Jane Goodall Institut Schweiz
Switzerland

Postfach 2807

8033 Zürich, Switzerland 
the adjacent Montagne d'Ambre National Park (e.g. Station des Roussettes, mean 2,378 mm). As a result the vegetation of the Forêt d'Ambre is distinctly mesic and has been described as transitional between lowland rainforest (at higher elevations) and dry deciduous western forest (at lower elevations) (White 1983, Raxworthy and Nussbaum 1994). Due to its close proximity to the town of Antsiranana and other large communes such as Sakaramy and Joffreville, the forest is also characterized by semi-disturbed and heavily degraded areas of anthropogenically altered habitat.

The partial isolation of the low altitude dry deciduous forest of this site from the five other major localized areas of dry deciduous forest (Analamera, Ankarana, Daraina, Montagne des Français and Orangea) located in the extreme north of Madagascar is believed to be as a result of human settlement [estimated at approximately 1,500-2,000 years ago (Hurles et al. 2005)] and subsequent anthropogenic deforestation (Vallan 2000, Vallan 2002, D'Cruze et al. 2006). However, it is important to note that the sub-arid habitats which separate the rainforest within the Montagne d'Ambre complex from the rest of the major eastern rainforest block do not appear to have been created by the same recent human activity (Raxworthy and Nussbaum 1994). As the Montagne d'Ambre mountain complex is volcanic in origin, composed of basaltic rock formed about 14 million years ago (Du Puy and Moat 1996), it probably received more continuous precipitation during dry periods to support a forest cover which may have been partially isolated for millions of years from other northern and eastern forest blocks (Raxworthy and Nussbaum 1994).

The Forêt d'Ambre special Reserve with a surface area of 4,810 ha $\left(\mathrm{S} 12^{\circ} 20^{\prime}-\mathrm{S} 12^{\circ} 30^{\prime}, \mathrm{E} 49^{\circ} 09^{\prime}-\mathrm{E} 49^{\circ} 14^{\prime}\right)$ was formally created in 1958. This IUCN Category II protected area includes forest between 150 and 1,143 $\mathrm{m}$ a.s.I. and is characterized by numerous high-standing hills, ridges and plateaus interspersed with valleys, channels and gullies. Several rivers and streams flow through the Reserve and a permanent body of water known locally as Lac Mahery can be found at $343 \mathrm{~m}$ a.s.I. Further protection is provided to forest in this mountain range by the adjacent Montagne d'Ambre National Park (18,200 ha) which was also created in 1958. Both the Forêt d'Ambre special Reserve and the Montagne d'Ambre National Park are currently managed by ANGAP ('Association Nationale pour la Gestion des Aires Protégées'). In addition, a small privately owned and managed area of forest known as the 'Fontenay Nature Park' borders both of these protected areas.

Madagascar is blessed with a rich herpetofauna comprising over 600 species of reptiles and amphibians, more than $95 \%$ of which are endemic to the Malagasy region (Glaw and Vences 2007). Based on specific combinations of climate, topography and vegetation, Madagascar has been traditionally divided into five or six biogeographic zones (Cornet 1974, Schatz 2000), More recently, Wilmé et al. (2006) divided the island into 10 areas of endemism according to the main watersheds and species distribution data. Among these, the areas characterized by humid rainforest (predominantly the east of the island) have attracted most of the attention from researchers because of their high biodiversity and advanced conservation needs. However, fieldwork conducted in recent years has begun to reveal the extraordinary importance of the extreme north as a biological center of herpetological diversity and endemism, which has included the discovery of a multitude of undescribed herpetological taxa (Raxworthy and Nussbaum 1994, Mori et al. 2006, D'Cruze et al. 2006, 2007, Rakotondravony 2006).

Despite the relatively old age of the Special Reserve and the interesting biogeographic history of the site, prior to this study virtually nothing was known about its herpetofauna. Specimens had been collected from the Montagne d'Ambre complex for more than 100 years, with the earliest herpetological collection (deposited in the Musée National d'Histoire Naturelle, Paris) made by Alluaud and Belly in 1893 (Mocquard 1895). Typically, however these specimens lack precise locality data, which is a significant problem because of the wide elevational range and diverse array of habitat types in the region. Species were often represented by a single specimen, which made it impossible to understand character variation within local populations and increased the risk of taxonomic errors. As a result no comprehensive species list for the amphibians and reptiles of the Forêt d'Ambre Special Reserve has ever been published. In contrast several vertebrate species lists have been produced for the adjacent Montagne d'Ambre National Park (IUCN / UNEP / WWF 1987, Nicoll and Langrand 1989, Andreone 1991, Raxworthy and Nussbaum 1994). However, even the most recent survey conducted by Raxworthy and Nussbaum (1994) was done over a decade ago and is in need of revision in order to keep up with new discoveries and taxonomic progress.

Given the lack of published information regarding this important site of conservation, we conducted a rapid survey of amphibians and reptiles in order to (1) update the existing knowledge regarding the composition, geographical and ecological distribution of the herpetofauna of the Forêt d'Ambre Special Reserve, (2) highlight the herpetological diversity of this area and identify the current threats to its conservation, (3) review the existing conservation initiatives and (4) provide recommendations that will facilitate the development of an effective and sustainable management plan for the reserve. We also take the opportunity to provide a preliminary species list for the Fontenay Nature Park and an updated species list for the Montagne d'Ambre National Park.

STUDY SITES Field work was centered at two camps

situated along the road which runs along the eastern edge of the Reserve from Sakaramy to Joffreville, which facilitated exploration of the full altitudinal range found within the Forêt d'Ambre Special Reserve and adjacent unprotected areas (150-1,143 m). Camp 1, Hotely Tsara 'Lasopy' Antanambetsara, S12 $27.98^{\prime}, \mathrm{E} 49^{\circ} 13.82^{\prime}, 454 \mathrm{~m}$ altitude, adjacent to low altitude rainforest, was occupied from 18 to 25 February 2008. Camp 2, Le Domaine de Fontenay, S12²9.70', E49012.15', 720 $\mathrm{m}$ altitude, also adjacent to low altitude rainforest, was occupied from 25 to 29 February 2008. In addition, short excursions were carried out by a second team in the Fontenay Nature Park (S12 ${ }^{\circ} 29.70^{\prime}$, E49012.15', between 19 and 28 February 2008) and to the Lac Mahery (27 February 2008). An initial excursion to Forêt d'Ambre was carried out on 12 March 2007. Fieldwork in Montagne d'Ambre National Park was carried out by many different research teams during several excursions between 1994 and 2008 and most of the results are summarized in Glaw and Vences (2007). 


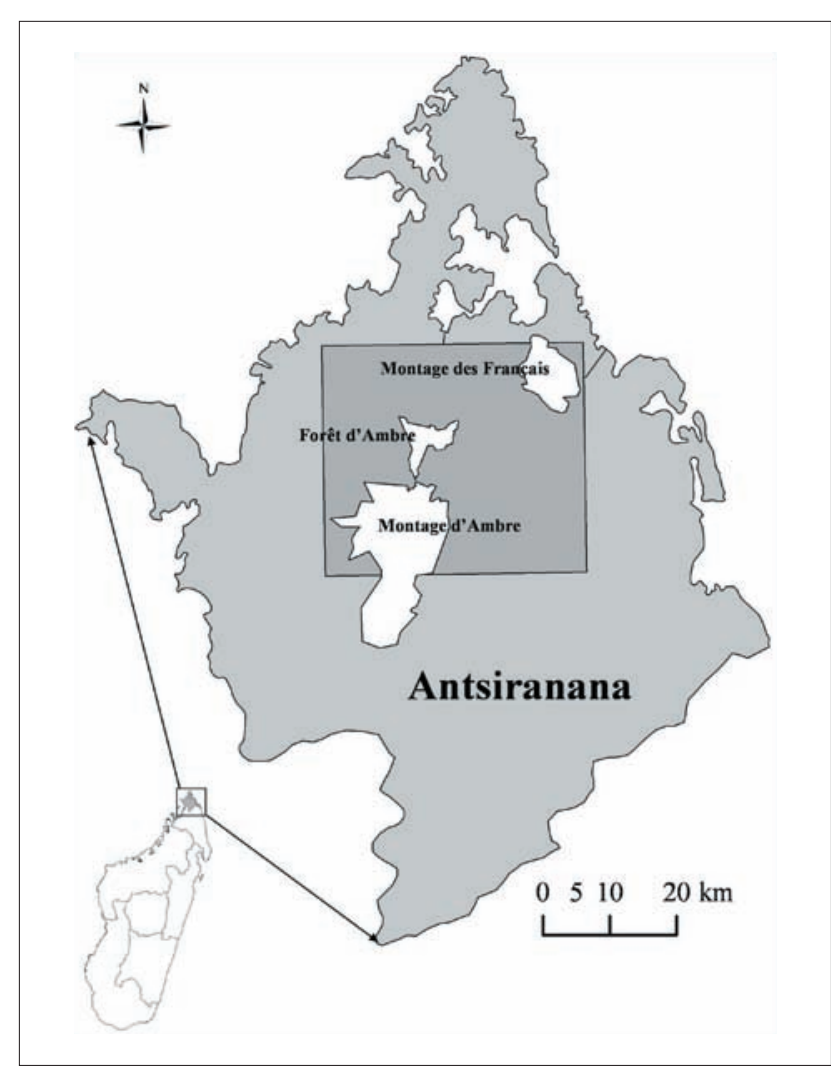

FIGURE 1. Map of northern Madagascar. The grey square depicts the location of the Forêt d'Ambre Special Reserve, the Montagne d'Ambre National Park and Montagne des Français within the Antsiranana Province.

\section{MATERIALS AND METHODS}

Due to the lack of field information regarding the herpetofauna of Fôret d'Ambre we used a wide range of sampling methods in order to collect data for as many species as possible. The main survey techniques we utilized were pitfall trapping with drift fences, opportunistic searching, refuge examination, and searching for calling frogs. We also made a concerted effort to identify anthropogenic activities that represent threats to the conservation of this area. We used three $100 \mathrm{~m}$ pitfall traplines with drift fences as described in Raxworthy and Nussbaum (1994), which were left in place for a total of eight days. We conducted opportunistic searches ( $D^{\prime}$ Cruze et al. 2007) across the full range of altitudes and habitats - night and day searching - in order to reveal the presence of species not captured by the other methods. We also made direct counts along line transects to identify species and assess their distribution and abundance. We specifically targeted calling anurans after rainfall. We classified the species encountered during this survey using a system similar to that used by Wilson and McCranie (2004) and D'Cruze et al. $(2006,2007)$ that can be summarized as follows: Abundant (large numbers encountered on a regular basis), common (encountered on a regular basis), infrequent (unpredictable, few individuals seen), or rare (rarely seen). These classifications are based on data collected using all survey techniques and refer to the total number of individuals encountered for each species. Finally we also estimated the altitudinal range for all of the species currently recorded from the Montagne $d^{\prime}$ Ambre complex. We used the minimum and maximum elevations [combined data of our surveys and that of Raxworthy and Nussbaum (1994)] to calculate the elevational range of each

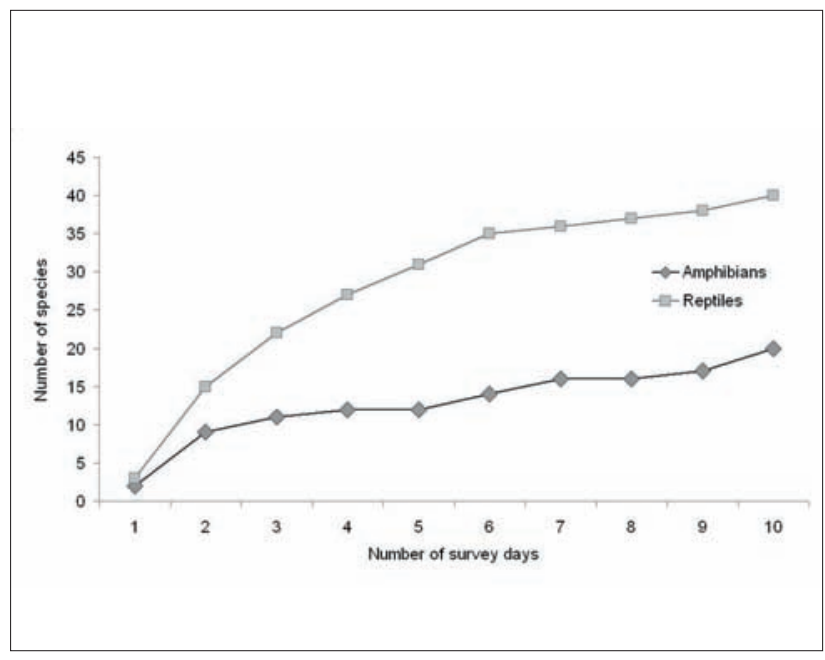

FIGURE 2. Species accumulation curve for amphibians and reptiles found in this study at the Forêt d'Ambre Special Reserve.

species. This method makes the assumption that each species is distributed continuously through the minimum and maximum elevation recorded.

The following information was recorded for each collected specimen: date, latitude, longitude, habitat, microhabitat and altitude. We also made color notes and took photographs. We took voucher specimens (preserved in $70 \%$ ethanol) and tissue samples for all voucher specimens. Reptile and amphibian specimens were deposited at the Zoologische Staatssammlung München (ZSM) and at the Université d'Antananarivo, Département de Biologie Animale (UADBA). A list of specimens can be found in Appendix I.

\section{RESULTS}

During this survey we recorded a total of 20 amphibian and 39 reptile species in the Forêt d'Ambre, giving a total herpetofaunal diversity of 59 species. A single species, Madascincus cf. polleni, was the only species captured in the pitfall traps. Explicit details of pitfall trap captures are not provided as they yielded very poor results. The species accumulation curves (Figure 2) indicate that we did not encounter all the reptile and amphibian species present in the area. However, it can now be assumed that the herpetofauna of Forêt d'Ambre consists of at least 24 species of lizard (41\%), 15 snakes (25\%) and 20 anurans (34\%). We classify a total of 3 species (5\%) as abundant, 14 (24\%) as common, 21 (36\%) as infrequent and $21(36 \%)$ as rare (Table 1). A complete species list is given in Table 1 along with the current CITES listing (CITES species Database, Geneva, Switzerland) and IUCN status (IUCN Red List of Threatened Species 2007, Species Survival Commission, Gland, Switzerland) for each of the relevant species. Table 1 also includes ecological data for each species including habitat type (classified as either forest or anthropogenically disturbed habitat), ecological distribution and relative abundance. We also provide a preliminary species list of amphibians and reptiles for the Fontenay Nature Park containing 36 species as well as an updated species list for the Montagne d'Ambre National Park including 75 species (Table 2). Photographic evidence of some of the species encountered during this study are provided in Figure 3 Plate A - D. 
TABLE 1. Conservation Status and distribution of the amphibian and reptile species found in Forêt d'Ambre Special Reserve during this study. Abbreviations: Relative Abundance: $\mathrm{A}=$ abundant, $\mathrm{C}=$ common, $\mathrm{I}=$ infrequent, $\mathrm{R}=$ rare; Ecological Distribution: $\mathrm{AB}=$ arboreal, $\mathrm{T}=$ terrestrial, $\mathrm{S}=\mathrm{semiaquatic}$; Habitat: $\mathrm{F}=$ forest, $\mathrm{A}=$ anthropogenically disturbed habitat; Endemicity: $\mathrm{E}=$ endemic to Madagascar, $\mathrm{RE}=$ endemic to the north of Madagascar (regional endemic), $\mathrm{N}=$ not endemic to Madagascar.

\begin{tabular}{|c|c|c|c|c|c|c|}
\hline Species & IUCN & CITES & Relative Abundance & Ecological Distribution & Habitat & Endemic \\
\hline \multicolumn{7}{|l|}{ Amphibia } \\
\hline \multicolumn{7}{|l|}{ Microhylidae } \\
\hline Cophyla sp. nov. & & & $\mathrm{R}$ & $A B$ & A & $\mathrm{RE}$ \\
\hline Platypelis grandis & LC & & $\mathrm{R}$ & $A B$ & $\mathrm{~F}$ & $E$ \\
\hline Rhombophryne sp. nov. & & & C & $\mathrm{T}$ & $\mathrm{F}$ & $\mathrm{RE}$ \\
\hline Stumpffia sp. & & & $\mathrm{C}$ & $\mathrm{T}$ & $\mathrm{F}$ & $\mathrm{RE}$ \\
\hline \multicolumn{7}{|l|}{ Ptychadenidae } \\
\hline Ptychadena mascareniensis & LC & & C & T, S & A & $E$ \\
\hline \multicolumn{7}{|l|}{ Mantellidae } \\
\hline Aglyptodactylus madagascariensis & LC & & I & $\mathrm{T}$ & $A, F$ & $E$ \\
\hline Aglyptodactylus securifer & LC & & 1 & $\mathrm{~T}$ & $A, F$ & $E$ \\
\hline Blommersia wittei & LC & & A & $\mathrm{T}$ & $\mathrm{F}$ & $\mathrm{E}$ \\
\hline Boophis baetkei & EN & & $\mathrm{R}$ & $A B$ & $\mathrm{~F}$ & $\mathrm{RE}$ \\
\hline Boophis brachychir & DD & & I & $A B$ & $\mathrm{~F}$ & $\mathrm{RE}$ \\
\hline Boophis septentrionalis & DD & & I & $A B$ & $\mathrm{~F}$ & $\mathrm{RE}$ \\
\hline Boophis sp. nov. aff. brachychir & & & $\mathrm{R}$ & $A B$ & $\mathrm{~F}$ & $\mathrm{RE}$ \\
\hline Boophis sp. nov. aff. madagascariensis "north" & & & । & $A B$ & $\mathrm{~F}$ & $\mathrm{RE}$ \\
\hline Boophis tephraeomystax & LC & & 1 & $A B, T$ & $A, F$ & $\mathrm{E}$ \\
\hline Gephyromantis granulatus & LC & & I & $\mathrm{T}, \mathrm{S}$ & $\mathrm{F}$ & $\mathrm{RE}$ \\
\hline Gephyromantis pseudoasper & LC & & I & $\mathrm{T}, \mathrm{S}$ & $\mathrm{F}$ & $\mathrm{RE}$ \\
\hline Mantella viridis & EN & ॥ & $\mathrm{R}$ & $\mathrm{T}$ & $\mathrm{F}$ & $\mathrm{RE}$ \\
\hline Mantidactylus ambreensis & LC & & । & T, S & $\mathrm{F}$ & $\mathrm{RE}$ \\
\hline Mantidactylus bellyi & & & C & T, S & $\mathrm{F}$ & $\mathrm{RE}$ \\
\hline Mantidactylus aff. betsileanus & & & $\mathrm{R}$ & T, S & $\mathrm{F}$ & $\mathrm{RE}$ \\
\hline \multicolumn{7}{|l|}{ Reptilia } \\
\hline \multicolumn{7}{|l|}{ Chamaeleonidae } \\
\hline Brookesia ebenaui & & $\|$ & C & $A B$ & $\mathrm{~F}$ & $\mathrm{RE}$ \\
\hline Brookesia sp. nov. & & (II) & $\mathrm{C}$ & $A B$ & $\mathrm{~F}$ & $\mathrm{RE}$ \\
\hline Brookesia stumpffi & & II & C & $A B$ & $\mathrm{~F}$ & $E$ \\
\hline Furcifer oustaleti & & ॥ & A & $A B$ & A & E \\
\hline Furcifer pardalis & & ॥ & A & $A B$ & $A, F$ & $E$ \\
\hline Furcifer petteri & & ॥ & C & $A B$ & $\mathrm{~F}$ & $\mathrm{RE}$ \\
\hline \multicolumn{7}{|l|}{ Gekkonidae } \\
\hline Blaesodactylus boivini & & & C & $A B$ & $A, F$ & $\mathrm{RE}$ \\
\hline Geckolepis cf. maculata & & & $\mathrm{R}$ & $A B$ & $\mathrm{~F}$ & $\mathrm{E}$ \\
\hline Hemidactylus frenatus & & & I & $A B$ & A & $\mathrm{N}$ \\
\hline Lygodactylus cf. heterurus & & & $\mathrm{R}$ & $A B$ & A & $\mathrm{RE}$ \\
\hline Paroedura cf. oviceps & & & 1 & $\mathrm{~T}$ & $\mathrm{~F}$ & $E$ \\
\hline Paroedura stumpffi & & & I & $\mathrm{T}$ & $\mathrm{F}$ & $\mathrm{E}$ \\
\hline Phelsuma abbotti chekei & $\mathrm{LC}$ & II & I & $A B$ & A & $E$ \\
\hline Phelsuma lineata dorsivittata & & ॥ & । & $A B$ & $A, F$ & $E$ \\
\hline Phelsuma grandis & & ॥ & $\mathrm{C}$ & $A B$ & $A, F$ & $\mathrm{E}$ \\
\hline Uroplatus alluaudi & & ॥ & $\mathrm{R}$ & $A B$ & A & $\mathrm{RE}$ \\
\hline Uroplatus sp. nov. aff. ebenaui & & ॥ & $\mathrm{R}$ & $A B$ & $A, F$ & $E$ \\
\hline Uroplatus sp. nov. aff. henkeli & & II & C & $A B$ & $A, F$ & $E$ \\
\hline Uroplatus sikorae & & II & C & $A B$ & $A, F$ & E \\
\hline Uroplatus giganteus & & ॥ & 1 & $A B$ & $A, F$ & $\mathrm{RE}$ \\
\hline \multicolumn{7}{|l|}{ Gerrhosauridae } \\
\hline Zonosaurus haraldmeieri & & & I & $\mathrm{T}$ & $\mathrm{F}$ & $\mathrm{RE}$ \\
\hline \multicolumn{7}{|l|}{ Scincidae } \\
\hline Madascincus cf. polleni & & & । & $\mathrm{T}$ & $\mathrm{F}$ & $E$ \\
\hline
\end{tabular}




\begin{tabular}{|c|c|c|c|c|c|}
\hline Trachylepis elegans & & । & T & A & $E$ \\
\hline Trachylepis tavaratra & & । & $\mathrm{T}$ & A & $\mathrm{RE}$ \\
\hline \multicolumn{6}{|l|}{ Boidae } \\
\hline Sanzinia madagascariensis volontany & VU & । & $A B, T$ & $A, F$ & $E$ \\
\hline \multicolumn{6}{|l|}{ Colubridae sensu lato } \\
\hline Alluaudina bellyi & & C & $\mathrm{T}$ & $A, F$ & $E$ \\
\hline Dromicodryas quadrilineatus & & $\mathrm{R}$ & $\mathrm{T}$ & A & $E$ \\
\hline Ithycyphus miniatus & & $\mathrm{R}$ & $A B$ & A & E \\
\hline Leioheterodon madagascariensis & & C & $\mathrm{T}$ & $A, F$ & $E$ \\
\hline Leioheterodon modestus & & $\mathrm{R}$ & $\mathrm{T}$ & A & $E$ \\
\hline Liophidium torquatum & & । & $\mathrm{T}$ & $\mathrm{F}$ & $E$ \\
\hline Mimophis mahfalensis & & $\mathrm{R}$ & $\mathrm{T}$ & A & $E$ \\
\hline Pseudoxyrhopus microps & & $\mathrm{R}$ & $\mathrm{T}$ & A & $E$ \\
\hline Pseudoxyrhopus cf. quinquelineatus & & $\mathrm{R}$ & $\mathrm{T}$ & $?$ & $E$ \\
\hline Stenophis granuliceps & & $\mathrm{R}$ & $A B$ & $\mathrm{~F}$ & $\mathrm{RE}$ \\
\hline Stenophis inopinae & & $\mathrm{R}$ & $A B$ & $\mathrm{~F}$ & $\mathrm{RE}$ \\
\hline Stenophis cf. variabilis & & $\mathrm{R}$ & $A B$ & $\mathrm{~F}$ & E \\
\hline Thamnosophis lateralis & & $\mathrm{R}$ & $\mathrm{T}$ & $\mathrm{F}$ & $E$ \\
\hline Thamnosophis martae & & $\mathrm{R}$ & $\mathrm{T}$ & $\mathrm{F}$ & $E$ \\
\hline
\end{tabular}
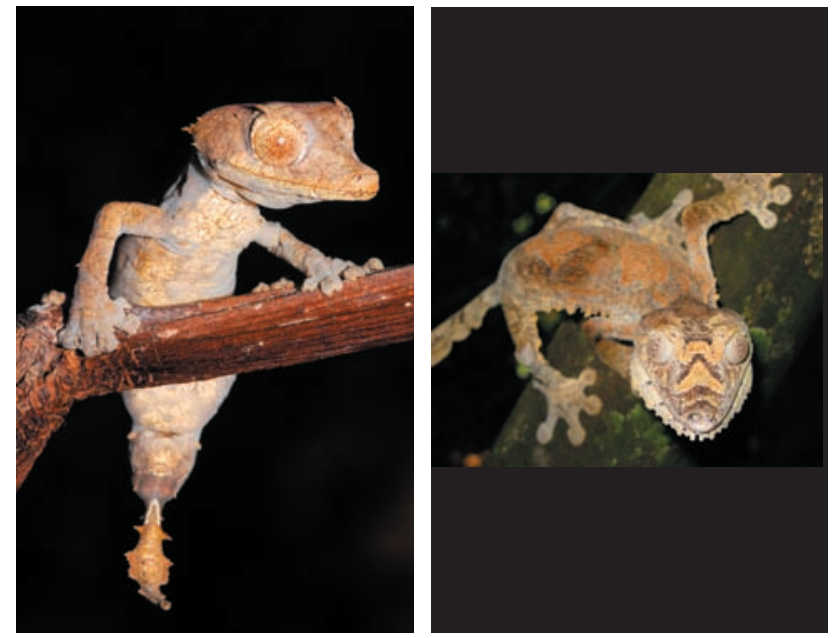

Plate A: Uroplatus sp. nov. aff. ebenaui Plate B: Uroplatus giganteus

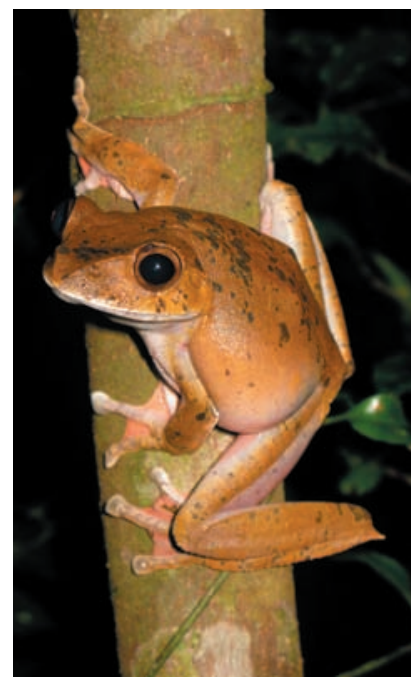

Plate C: Boophis sp. nov. aff. madagascariensis "north"

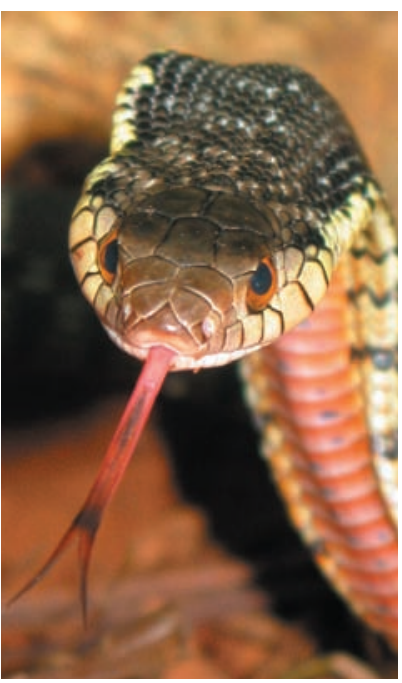

Plate D: Leioheterodon madagascariensis

FIGURE 3. Photographic documentation of some of the species encountered in Forêt d'Ambre.
BIOGEOGRAPHY AND CONSERVATION STATUS Almost

all of these species are naturally endemic to Madagascar, with just one, Hemidactylus frenatus, known for its cosmopolitan distribution. The following species are currently known only from this special Reserve: Boophis baetkei, Brookesia sp. nov., and Rhombophryne sp. nov. Furthermore, we recorded 25 species (42\%) that are regional endemics restricted to only a few places in north Madagascar (Table 1). Two species are listed as data deficient, two are listed as endangered (as of the original description, see Köhler et al. 2008), one is listed as vulnerable and 10 are listed as least concern on the 2007 IUCN Red List of Threatened Species. A total of 15 species are listed on the CITES appendices.

HABITAT AND DISTRIBUTION with regards to habitat

quality, 30 species (51\%), were only observed in relatively undisturbed forest (Table 1). A total of 14 species (24\%) were observed in both forest and anthropogenically disturbed habitat. Only 14 species (24\%) were observed in anthropogenically disturbed habitat. In terms of vertical positioning within the undisturbed habitat, we found 22 species (37\%) only in terrestrial situations, 29 (49\%) only in typically arboreal situations, and 2 (3\%) in both (Table 1). We observed six species (10\%) in both semi-aquatic and terrestrial situations.

ALTITUDINAL DISTRIBUTION The altitudinal distribution

of the amphibians and reptiles is restricted in most cases to just a portion of the full altitudinal range of the Montagne d'Ambre complex. A distinct transitional altitude is apparent for many species at $900 \mathrm{~m}$. Of the 59 species encountered at Forêt d'Ambre Special Reserve during this survey, 36 (61\%) have been found exclusively at or below $900 \mathrm{~m}$ and 22 (37\%) have been found above and below $900 \mathrm{~m}$ (Table 2).

\section{DISCUSSION}

AN IMPORTANT SITE OF HERPETOLOGICAL DIVERSITY

AND ENDEMISM The extremely high level of regional endemism seen in the herpetofauna, immediately emphasizes the value of the Forêt d'Ambre special Reserve as a key site 
TABLE 2. Inventory list and altitudinal distribution for the amphibian and reptile species of Montagne d'Ambre National Park, Fontenay Nature Park and the Forêt d'Ambre Special Reserve (see text for literature sources): Survey Data: + = present; Altitude: ? = unknown.

\begin{tabular}{|c|c|c|c|c|}
\hline Species & Montagne d'Ambre & Fontenay & Forêt d'Ambre & Altitude \\
\hline \multicolumn{5}{|l|}{ Amphibia } \\
\hline \multicolumn{5}{|l|}{ Microhylidae } \\
\hline Cophyla sp. nov. & + & + & + & $500-1,250$ \\
\hline Platypelis grandis & + & & + & $550-1,050$ \\
\hline Rhombophryne laevipes & + & & & $900-1,200$ \\
\hline Rhombophryne sp. nov. & & & + & $400-500$ \\
\hline Stumpffia sp. 1 & + & & & $600-1,250$ \\
\hline Stumpffia sp. 2 & + & + & + & $400-650$ \\
\hline \multicolumn{5}{|l|}{ Hyperoliidae } \\
\hline Heterixalus cf. carbonei & + & & & 1,000 \\
\hline \multicolumn{5}{|l|}{ Mantellidae } \\
\hline Aglyptodactylus madagascariensis & + & + & + & $650-1,200$ \\
\hline Aglyptodactylus securifer & & + & + & $400-650$ \\
\hline Blommersia wittei & + & + & + & $300-1,000$ \\
\hline Boophis baetkei & & & + & $400-500$ \\
\hline Boophis blommersae & + & + & & $650-1,050$ \\
\hline Boophis brachychir & & & + & $400-500$ \\
\hline Boophis septentrionalis & + & + & + & $650-1,150$ \\
\hline Boophis sp. nov. aff. brachychir & + & & + & $650-1,050$ \\
\hline Boophis sp. nov. aff. madagascariensis "north" & + & + & + & $500-1,050$ \\
\hline Boophis tephraeomystax & + & + & + & $100-1,000$ \\
\hline Gephyromantis ambohitra & + & & & $900-1,050$ \\
\hline Gephyromantis granulatus & + & + & + & $400-1,250$ \\
\hline Gephyromantis cf. horridus & + & & & $1,000-1,200$ \\
\hline Gephyromantis pseudoasper & + & + & + & $400-900$ \\
\hline Guibemantis aff. bicalcaratus & + & & & $950-1,200$ \\
\hline Guibemantis liber & + & & & $1,000-1,150$ \\
\hline Mantella viridis & & & + & $100-200$ \\
\hline Mantidactylus ambreensis & + & + & + & $400-1,150$ \\
\hline Mantidactylus bellyi & + & + & + & $400-1,150$ \\
\hline Mantidactylus aff. betsileanus & + & & + & $450-1,050$ \\
\hline Mantidactylus femoralis & + & & & $650-1,150$ \\
\hline \multicolumn{5}{|l|}{ Ptychadenidae } \\
\hline Ptychadena mascareniensis & + & + & + & $100-1,200$ \\
\hline \multicolumn{5}{|l|}{ Reptilia } \\
\hline \multicolumn{5}{|l|}{ Chamaeleonidae } \\
\hline Brookesia ambreensis & + & & & $650-1,050$ \\
\hline Brookesia antakarana & + & & & $650-1,050$ \\
\hline Brookesia ebenaui & + & + & + & $400-800$ \\
\hline Brookesia sp. nov. & & & + & $400-500$ \\
\hline Brookesia stumpffi & + & + & + & $400-1,200$ \\
\hline Brookesia tuberculata & + & & & $900-1,100$ \\
\hline Calumma amber & + & & & $900-1,300$ \\
\hline Calumma ambreense & + & & & $900-1,250$ \\
\hline Calumma boettgeri & + & & & $650-1,250$ \\
\hline Calumma nasutum & + & & & 900 \\
\hline Furcifer oustaleti & & + & + & $400-650$ \\
\hline Furcifer pardalis & + & + & + & $400-900$ \\
\hline Furcifer petteri & + & + & + & $400-700$ \\
\hline Furcifer sp. nov. & + & & & $800-900$ \\
\hline \multicolumn{5}{|l|}{ Gekkonidae } \\
\hline Blaesodactylus boivini & & & + & $400-600$ \\
\hline Ebenavia inunguis & + & & & 650 \\
\hline
\end{tabular}




\begin{tabular}{|c|c|c|c|c|}
\hline Geckolepis cf. maculata & + & + & + & $400-650$ \\
\hline Hemidactylus frenatus & & & + & $100-400$ \\
\hline Lygodactylus madagascariensis & + & + & & $650-1,200$ \\
\hline Lygodactylus cf. heterurus & & & + & $100-200$ \\
\hline Paroedura cf. gracilis & + & & & $850-900$ \\
\hline Paroedura cf. oviceps & + & & + & $400-800$ \\
\hline Paroedura stumpffi & + & + & + & $400-700$ \\
\hline Phelsuma abbotti chekei & & & + & $400-500$ \\
\hline Phelsuma grandis & + & + & + & $400-900$ \\
\hline Phelsuma lineata dorsivittata & + & + & + & $500-1,100$ \\
\hline Uroplatus alluaudi & + & & + & $750-950$ \\
\hline Uroplatus giganteus & + & + & + & $400-850$ \\
\hline Uroplatus sp. nov. aff. henkeli & & + & + & $400-650$ \\
\hline Uroplatus sikorae & + & & + & $650-1,000$ \\
\hline Uroplatus sp. nov. aff. ebenaui & + & & + & $400-1,200$ \\
\hline \multicolumn{5}{|l|}{ Gerrhosauridae } \\
\hline Zonosaurus haraldmeieri & + & + & + & $400-1,000$ \\
\hline \multicolumn{5}{|l|}{ Scincidae } \\
\hline Amphiglossus alluaudi & + & & & $?$ \\
\hline Amphiglossus mandokava & + & & & 950 \\
\hline Amphiglossus melanurus & + & & & $1^{\prime} 100$ \\
\hline Madascincus melanopleura & + & & & $900-1,250$ \\
\hline Madascincus mouroundavae & + & & & $900-1,250$ \\
\hline Madascincus cf. polleni & + & & + & $400-650$ \\
\hline Paracontias brocchii & + & & & $900-1,250$ \\
\hline Paracontias hildebrandti & + & & & $600-700$ \\
\hline Trachylepis elegans & + & + & + & $300-850$ \\
\hline Trachylepis tavaratra & & & + & $300-500$ \\
\hline \multicolumn{5}{|l|}{ Boidae } \\
\hline Sanzinia madagascariensis volontany & + & + & + & $400-950$ \\
\hline \multicolumn{5}{|l|}{ Colubridae sensu lato } \\
\hline Alluaudina bellyi & + & + & + & $400-650$ \\
\hline Compsophis albiventris & + & & & $900-1,250$ \\
\hline Compsophis infralineatus & + & & & 650 \\
\hline Dromicodryas quadrilineatus & & & + & $400-500$ \\
\hline Exallodontophis albignaci & + & & & 650 \\
\hline Ithycyphus miniatus & & & + & $400-500$ \\
\hline Leioheterodon madagascariensis & + & + & + & $100-1,000$ \\
\hline Leioheterodon modestus & & + & + & $400-650$ \\
\hline Liophidium rhodogaster & + & & & $850-1,150$ \\
\hline Liophidium sp. & + & & & 650 \\
\hline Liophidium torquatum & + & + & + & $400-950$ \\
\hline Liopholidophis dimorphus & + & & & $800-900$ \\
\hline Mimophis mahfalensis & & & + & $400-500$ \\
\hline Pseudoxyrhopus ambreensis & + & & & $900-1,200$ \\
\hline Pseudoxyrhopus cf. quinquelineatus & & & + & $?$ \\
\hline Pseudoxyrhopus microps & + & + & + & $500-650$ \\
\hline Stenophis granuliceps & + & + & + & $400-800$ \\
\hline Stenophis inopinae & & & + & $400-500$ \\
\hline Stenophis cf. variabilis & + & + & + & $400-800$ \\
\hline Thamnosophis lateralis & + & & + & $300-900$ \\
\hline Thamnosophis martae & & & + & $400-500$ \\
\hline \multicolumn{5}{|l|}{ Typhlopidae } \\
\hline Typhlops microcephalus & + & & & $650-1,200$ \\
\hline Typhlops cf. mucronatus & + & & & 650 \\
\hline TOTAL & 75 & 36 & 59 & - \\
\hline
\end{tabular}


of herpetological conservation importance. Due to its isolation from the rest of the eastern rainforest belt and the forests of the Sambirano region, the humid lowland rainforest and transitional forest of the Forêt d'Ambre may have served as a biological refuge. Therefore it may have preserved relict populations of species that disappeared from other regions of the eastern rainforest belt during dry periods; or it may have facilitated speciation through geographic isolation (Raxworthy and Nussbaum 1994). Both of these factors would have produced endemics in the Forêt d'Ambre forest and therefore this reserve may contain species that are found nowhere else (Köhler et al. 2008).

With regards to habitat quality, approximately half of all the species were only observed in relatively undisturbed forest which highlights the conservation importance of this habitat (Table 1). Only approximately one quarter of the species were observed in both forest and anthropogenically disturbed habitat which indicates that these species are able to adapt to adverse human activities to at least some degree. The remaining species were only observed in anthropogenically disturbed habitat. It is possible that this is because these particular habitats suit their needs or because they are indifferent to habitat change. However, it is also possible that this is because there are specific aspects of their natural history (i.e. nocturnal, cryptic behavior) that makes them difficult to observe in the more structurally diverse forest habitat.

The relatively large elevational range within the Montagne d'Ambre complex (Forêt d'Ambre Special Reserve, Montagne d'Ambre National Park and the Fontenay Nature Park) makes it an interesting area in Madagascar to study elevational influences on patterns of species distribution. It is also crucial for future conservation initiatives focusing on this area that this ecological aspect is characterized to enable informed decisions. The transitional $900 \mathrm{~m}$ contour observed for many species corresponds closely to the transition between lowland rainforest and moist montane rainforest, which is indicated by White (1983) to be about $800 \mathrm{~m}$. The fauna of Forêt d'Ambre therefore appears to be largely composed of lowland rainforest species and some species that are also able to adapt to moist montane forest conditions found at the upper altitudes of the reserve.

RANGE EXTENSIONS This is the first published survey

to focus on this area. Consequently most of the species found were new records for this specific locality. However, several species encountered during this study require special mention as their occurrence in the Forêt d'Ambre significantly contributes to the current information regarding their distribution in Madagascar. The presence of Mantella viridis at this locality is noteworthy because this species, until recently considered as critically endangered [now changed to endangered by Andreone et al. (2008a)], was only known from few localities in the extreme north of Madagascar (Glaw and Vences 2007). Similarly, prior to this survey the Colubrid snake Thamnosophis martae was only known from Montagne des Français. The Giant leaf-tailed gecko uroplatus giganteus is also recorded from this reserve for the first time. This species is the second largest extant gecko in the world and is currently considered to be at serious conservation risk as a result of its limited distribution which is believed to be restricted to the Montagne d'Ambre mountain range (Glaw et al. 2006). This survey also extends the known habitat for several species that are more typically associated with dry deciduous forest: Blaesodactylus boivini, Leioheterodon modestus, Phelsuma abbotti and Stenophis inopinae.
MONTAGNE D'AMBRE The species accumulation curves

for Forêt d'Ambre (Figure 2) indicate that this rapid assessment (12 days of research) was not enough to allow for complete sampling at this location. In contrast, the herpetofauna of Montagne d'Ambre National Park has been surveyed intensively by different researchers since long (Mocquard 1895, Ramanantsoa 1974, Andreone 1991, Glaw and Vences 1994, 2007, Raxworthy and Nussbaum 1994). It is therefore remarkable that several species have also been discovered in this reserve only recently, including Boophis tephraeomystax, Mantidactylus aff. betsileanus, Furcifer sp. nov., Paroedura cf. gracilis, Amphiglossus mandokava, and Stenophis granuliceps. These findings indicate that even intensive surveys, conducted by numerous researchers using different methods may often fail to obtain a complete herpetofaunal species inventory in rainforest areas of Madagascar which usually harbour a large amount of species.

ANTHROPOGENIC THREATS Socio-economic factors

such as rapid population growth, poor education and other particular aspects of Malagasy culture are partly responsible for obliging local residents to employ harmful agricultural methods and other activities that lead to the exploitation of natural resources (Durbin et al. 2003) which can be a serious threat to amphibians and reptiles (Glaw and Vences 2007). As a result of its close proximity to the administrative capital of the Antsiranana province (ca. $30 \mathrm{~km}$ ) and neighbouring communes such as Sakaramy and Joffreville, the unique biodiversity of this Special Reserve is particularly vulnerable to these anthropogenic pressures.

Indeed, our study revealed that the unique fauna of the Forêt d'Ambre is under immediate threat from numerous anthropogenic pressures that are currently being conducted within the Special Reserve despite its protective status. The major threats to the integrity of the herpetofauna of this area are: (1) agricultural clearance for banana, coffee, khat, maize, papaya, and rice cultivation; (2) charcoal production; (3) timber production; (4) small scale quarrying; and (5) zebu grazing (Figure 4 Plate A-D). Sites are either selectively logged or cleared of all trees as a result of all of these practices which has resulted in the degradation or clearance of large areas of forest within the reserve. In addition, other vertebrate groups within this special Reserve are also under threat from subsistence hunting (researchers observed poachers with rifles targeting wetland bird species at Lac Mahery) and from feral cats and dogs, which were encountered on several occasions. Although illegal collection of reptiles and amphibians for the pet trade may have been taken place at this locality no evidence was gathered during this study.

These pressures on natural resources have already had a major impact at a national level [Myers et al. (2000) estimated that more than $90 \%$ of the original natural vegetation has already been lost in Madagascar] and are currently believed to constitute the most severe threat to reptiles and amphibians in Madagascar (Vallan 2002, 2003, Andreone et al. 2005, 2008b, Glaw and Vences 2007). Continued forest clearance will lead to the eventual fragmentation of the remaining areas of forest (with serious consequences on herpetofauna, e.g. Vallan 2000), followed by local and possibly complete extinctions that will in turn place increased pressure on the existing system of protected areas in the north of Madagascar. 


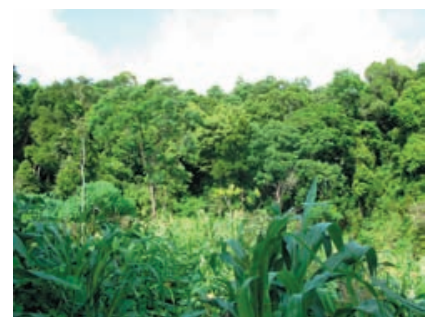

Plate A

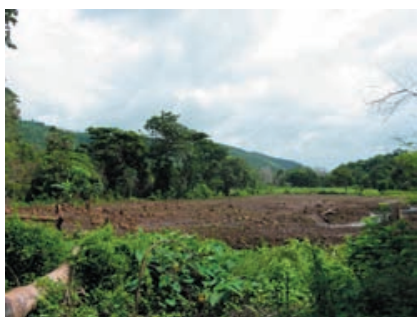

Plate B

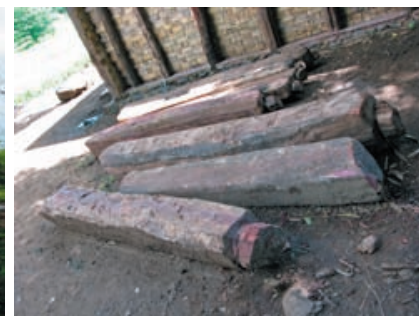

Plate C

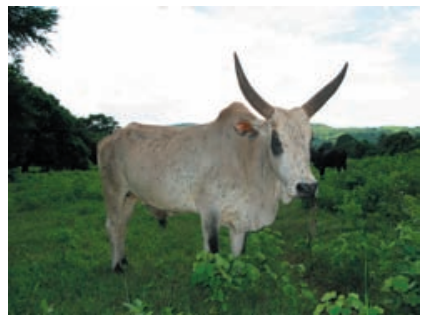

Plate D

FIGURE 4. Photographic documenation of clearings, plantations and other threats in Forêt d'Ambre.

Plate A: Banana plantation within the Forêt d'Ambre Special Reserve; Plate B: Agricultural clearance (for rice) within the Forêt d'Ambre Special Reserve; Plate C: Timber production within the Forêt d'Ambre Special Reserve; Plate D: Zebu grazing within the Forêt d'Ambre Special Reserve

EXISTING CONSERVATION INITIATIVES The extreme north of Madagascar is already recognized as one of the richest regions of the biodiversity hotspot that is Madagascar (e.g. Raxworthy and Nussbaum 1994, 1995, Andreone et al. 2003, Wilmé et al. 2006). In addition to the Montagne d'Ambre complex, this region contains five other major localized areas of forest (Analamera, Ankarana, Daraina, Montagne des Français and Orangea) and a plethora of much smaller more fragmented areas (e.g. Ampombofofo, Manondro, Nosy Hara, Windsor Castle). In order to protect these unique habitats from the anthropogenic threats highlighted above, existing conservation strategies are in place, which include the identification of priority areas in Madagascar for threatened or overall species diversity and their inclusion in protected nature reserves (Ganzhorn et al. 1997, ANGAP 2001, Kremen et al. 2008).

In theory these protected nature reserves are an effective means to protect tropical biodiversity and they can be successful at stopping land clearing, and to a lesser degree effective at mitigating logging, hunting, fire, and grazing (Bruner et al. 2001). However, it has also been demonstrated that their effectiveness correlates with basic management activities such as enforcement, boundary demarcation, and direct compensation to local communities (Bruner et al. 2001), which require substantial financial investment (Balmford and Whitten 2003). Furthermore, in practice the identification and management of priority areas has also been constrained by lack of information on the distribution, abundance, and habitat requirements of threatened species and the size, condition, and threats to survival of forest remnants (Smith et al. 1997). This type of baseline information is needed to integrate information relevant to existing conservation and development programmes and guide the course of future management strategies (Kremen et al. 1994). There is a distinct lack of funding and baseline biodiversity data for the majority of protected and non protected areas of forest in Madagascar which may explain the current situation at the Forêt d'Ambre special Reserve.

Internationally, in the past three decades conservation biologists have developed powerful tools for reserve selection and design (Kremen et al. 1999, 2008). Using fundamental biological and socioeconomic principles of modern conservation science, complex park proposals and management plans are developed that are specifically designed to balance human and wildife needs (Kremen et al. 1994). Created and relatively neglected since 1958, it is likely that the Reserve was not designed with the aim of preserving natural resources and biodiversity in concert with improving human well-being or the importance of the consent and support of local inhabitants (Kremen et al.1994). Furthermore it is also possible that the integrity of the biodiversity within the Forêt d'Ambre Special Reserve has also suffered as a result of its close proximity to the Montagne d'Ambre National Park. With limited funding and manpower it appears that ANGAP and previous management authorities have focused on the biodiversity in the moist montane forest found at the higher elevations.

FUTURE CONSERVATION INITIATIVES It is clear that

immediate increased conservation management action is required to protect the biological diversity found within the Forêt d'Ambre Special Reserve. We strongly suggest that this should be made effective immediately because of the relatively small surface area $(4,810$ ha) of this special reserve and the frequency and intensity of which anthropogenic disturbance was encountered during this survey. We predict that without immediate action the majority of the habitat in this Special Reserve will be subject to some form of adverse anthropogenic activity within the next five to 10 years. Based on the findings of this survey we provide conservation recommendations for this highly diverse site of herpetological importance:

- Establishment of an enforcement training programme which will produce forest wardens that will be able to patrol the existing core protected area and act as an active deterrent.

- $\quad$ Further assessment and monitoring of natural resource use activities. In particular, clearance of forest needs to be restricted and the remaining areas must be carefully monitored (e.g. by remote sensing using satellite data).

- Development of small scale eco-tourism (such as that employed at the Montagne d'Ambre National Park) as a workable alternative to non-sustainable resource use. Attractions and activities could include guided walks, boat trips and the utilization of specially designed bird hides.

- Development and implementation of a large-scale, regionally connected, more sustainable community-focused management system, which includes payments for ecosystem services, including biodiversity conservation and carbon sequestration.

- Development efforts, to promote sustainable agriculture practices and to improve human conditions. Village-based education programmes aimed at demonstrating alternative energy systems and crops, which are compatible with local traditions. 
- $\quad$ Raising awareness about environmental problems. Village-based programmes targeting all socioeconomic groups.

- Implementation of additional biodiversity surveys focused on the other major taxonomic groups found within the Forêt d'Ambre Special Reserve.

- Implementation of additional biodiversity surveys in the remaining protected areas in the Antsiranana Province.

\section{ACKNOWLEDGEMENTS}

We thank Parfait Bora, Hildegard Enting, Angelika Knoll, Zoltan Nagy, Marta Puente, Angelin and Angeluc Razafimanantsoa for their help in the field. We are very grateful to the Fontenay team (Raymond, Marie-José, Karl-Heinz) for their great hospitality and support during our fieldwork. The work was carried out in collaboration with the Département de Biologie Animale, Université d'Antananarivo, and the Association Nationale pour la Gestion des Aires Protégées (ANGAP). We are grateful to the Malagasy authorities, in particular the Ministère de l'Environnement et des Eaux et Forêts, for research and export permits. This survey was made possible by financial support of 'Act for Nature' and the engagement of his president, Olivier Arnoult, and the European Association of Zoos and Aquaria (EAZA). We also thank Paul Alibert and Jeremy Sabel for assisting with the provision of a French translation of the abstract.

\section{REFERENCES}

Andreone, F. 1991. Reptile field records from Malagasy rainforests. Bollettino del Museo Regionale di Scienze Naturali di Torino 9, 2: 437-460.

Andreone, F., Cadle, J. E., Cox, N., Glaw, F., Nussbaum, R. A., Raxworthy, C. J., Stuart, S., Vallan, D. and Vences, M. 2005. Species review of amphibian extinction risks in Madagascar: conclusions from the Global Amphibian Assessment. Conservation Biology 19, 6: 1790-1802.

Andreone, F., Cox, N., Glaw, F., Köhler, J., Rabibisoa, N. A. C., Randriamahazo, H., Randrianasolo, H., Raxworthy, C. J., Stuart, S., Vallan, D. and Vences, M. 2008a. Update of the Global Amphibian Assessment in light of species discoveries, nomenclature changes, and new field information. Monografie del Museo Regionale di Scienze Naturali di Torino, XLI.

Andreone, F., Glaw, F., Nussbaum, R. A., Raxworthy, C. J., Vences, M. and Randrianirina, J. E. 2003. The amphibians and reptiles of Nosy Be (NW Madagascar) and nearby islands: a case study of diversity and conservation of an insular fauna. Journal of Natural History 37, 17: 2119-2149.

Andreone, F., Carpenter, A. I., Cox, N., du Preez, L., Freeman, K., Furrer, S., Garcia, G., Glaw, F., Glos, J., Knox, D., Köhler, J., Mendelson III, J. R., Mercurio, V., Mittermeier, R. A., Moore, R. D., Rabibisoa, N. H. C., Randriamahazo, H., Randrianasolo, H., Rasoamampionona, N., Raminosoa, O., Ravoahangimalala Ramilijaona, Raxworthy, C. J., Vallan, D., Vences, M., Vieites, D. R. and Weldon, C. 2008b. The challenge of conserving amphibian megadiversity in Madagascar. PLoS Biology 6, 5: e118. doi: 10.1371/journal.pbio.0060118.

ANGAP (Association National pour la Gestion des Aires Protegées). 2001. Plan de gestion du réseau national des aires protégées de Madagascar. ANGAP and Ministrére de I'Environnement, Antananarivo, Madagascar.

Balmford, A. and Whitten, T. 2003. Who should pay for tropical conservation, and how could the costs be met? Oryx 37: 238-250.

Bruner, A. G., Gullison, R. E., Rice, R. E. and da Fonseca, G. A. B. 2001. Effectiveness of Parks in Protecting Tropical Biodiversity. Science 291: 125-128.

Cornet, A. 1974. Essai cartographique bioclimatique à Madagascar, carte à $1 / 2^{\prime} 000^{\prime} 000$ et notice explicative $N^{\circ} 55$. ORSTOM, Paris.

D'Cruze, N. C., Green, K. E., Robinson, J. E. and Gardner, C. J. 2006. A rapid assessment of the amphibians and reptiles of an unprotected area of dry deciduous forest in north Madagascar. Herpetological Bulletin 96: $17-25$.
D'Cruze, N., Sabel, J., Green, K., Dawson, J., Gardner, C., Robinson, J., Starkie, G., Vences, M. and Glaw, F. 2007. The first comprehensive survey of amphibians and reptiles at Montagne des Français, Madagascar. Herpetological Conservation and Biology 2, 2: 87-99.

Durbin, J., Bernard, K. and Fenn, M. 2003. The role of socio-economic factors in loss of Malagasy biodiversity. In: The Natural History of Madagascar, S. M. Goodman and J. P. Benstead (eds.), pp 142-146. The University of Chicago Press, Chicago.

Du Puy, D. and Moat, J. 1996. A refined classification of the primary vegetation of Madagascar based on the underlying geology: using GIS to map its distribution and to assess its conservation status. In: Proceedings of the International Symposium on Biogeography of Madagascar, W. R. Lourenco (ed.), pp 205-218. Editions de I'Orstrom, Paris.

Ganzhorn, J. U., Rakotosamimanana, B., Hannah, L., Hough, J., Iyer, L., Olivieri, S., Rajaobelina, S., Rodstrom, C. and Tilkin, G. 1997. Priorities for biodiversity conservation in Madagascar. Primate Report 48: 1-81.

Glaw, F., Kosuch, J., Henkel, F. W., Sound, P. and Böhme, W. 2006. Genetic and morphological variation of the leaf-tailed gecko Uroplatus fimbriatus from Madagascar, with description of a new giant species. Salamandra 42, 2: $129-144$

Glaw, F. and Vences, M. 1994. A fieldguide to the amphibians and reptiles of Madagascar. Second edition, Vences and Glaw Verlag, Köln.

Glaw, F. and Vences, M. 2007. A field guide to the amphibians and reptiles of Madagascar. Third edition, Vences and Glaw Verlag, Köln.

Hurles, M. E., Sykes, B. C., Jobling, M. A. and Forster, P. 2005. The dual origin of the Malagasy in island Southeast Asia and East Africa: evidence from maternal and paternal lineages. American Journal of Human Genetics 76: 894-901.

IUCN/UNEP/WWF. 1987. Madagascar, an environmental profile. M. D. Jenkins (ed). IUCN, Cambridge.

Köhler, J., Glaw, F. and Vences, M. 2008. Two additional treefrogs of the Boophis ulftunni species group (Anura: Mantellidae) discovered in rainforests of northern and south-eastern Madagascar. Zootaxa 1814: 37-48.

Kremen, C., Merenlender, A. M. and Murphy, D. D. 1994. Ecological monitoring: a vital need for integrated conservation and development programs in the tropics. Conservation Biology 8: 388-397.

Kremen, C., Razafimahatratra, V., Guillery, R. P., Rakotomalala, J., Weiss, A. and Ratsisompatrarivo, J. S. 1999. Designing the Masoala National Park in Madagascar based on biological and socioeconomic data. Conservation Biology 13: 1055-1068.

Kremen, C., Cameron, A., Moilanen, A., Phillips, S., Thomas, C. D., Beentje, H., Dransfield, J., Fisher, B. L., Glaw, F., Good, T. C., Harper, G. J., Hijmans, R. J., Lees, D. C., Louis Jr., E., Nussbaum, R. A., Raxworthy, C. J., Razafimpahanana, A., Schatz, G. E., Vences, M., Vieites, D. R., Wright, P. C. and Zjhra, M. L. 2008. Aligning conservation priorities across taxa in Madagascar, with high-resolution planning tools. Science 320: 222-226.

Mocquard, M. F. 1895. Sur les reptiles recueillis à Madagascar par M.M. Alluaud et Belly. Bulletin de la Société Philomathique, Paris, ser. 8, 7: 112-136.

Mori, A., Ikeuchi, I., and Hasegawa, M. 2006. Herpetofauna of Ampijoroa, Ankarafantsika Strict Nature Reserve, a dry forest in northwestern Madagascar. Herpetological Natural History 10, 1: 31-60.

Myers, N., Mittermeier, R. A., Mittermeier, C. G., da Fonseca, G. A. B. and Kent, J. 2000. Biodiversity hotspots for conservation priorities. Nature 403: 853-858.

Nicoll, M. E., and Langrand, O. 1989. Madagascar: Revue de la Conservation et des Aires Protégées. WWF Gland, Switzerland.

Rakotondravony, H. A. 2006. Aspects de la conservation des reptiles et des amphibiens dans la région de Daraina. Madagascar Conservation and Development 1, 1: 15-18.

Ramanantsoa, G. A.1974. Connaissance des Caméléonidés communs de la province de Diégo-Suarez par la population paysanne. Bulletin de l'Académie Malgache 51, 1: 147-149.

Raxworthy, C. J. and Nussbaum, R. A. 1994. A rainforest survey of amphibians, reptiles and small mammals at Montagne d'Ambre, Madagascar. Biological Conservation 69: 65-73.

Raxworthy, C. J. and Nussbaum, R. A. 1995. Systematics, speciation, and biogeography of the dwarf chameleons (Brookesia Gray; Reptilia, 
Squamata, Chamaeleontidae) of northern Madagascar. Journal of Zoology 235: 525-558

Schatz, G. E. 2000. Endemism in the Malagasy tree flora. In: Diversité et Endémisme à Madagascar, W. R. Lourenco and S. M. Goodman (eds.), pp 1-9. Mémoires de la Société de Biogéographie, Paris.

Smith, A. P., Horning, N., and Moore, D. 1997. Regional biodiversity planning and lemur conservation with GIS in western Madagascar. Conservation Biology 11: 498-512.

Vallan, D. 2000. Influence of forest fragmentation on amphibian diversity in the nature reserve of Ambohitantely, highland Madagascar. Biological Conservation 96: 31-43

Vallan, D. 2002. Effects of anthropogenic environmental changes on amphibian diversity in the rain forests of eastern Madagascar. Journal of Tropical Ecology 18: 725-742.

Vallan, D. 2003. Consequences of rain forest fragmentation for herpetofauna: a case study from Ambohitantely. In: The Natural History of Madagascar, S. M. Goodman and J. P. Benstead (eds.), pp 899-907. The University of Chicago Press, Chicago.

Wilmé, L., Goodman, S. M. and Ganzhorn, J. U. 2006. Biogeographic evolution of Madagascar's microendemic biota. Science 312: 1063-1065.

Wilson, L. D. and McCranie, J. R. 2004. The herpetofauna of Parque Nacional El Cusuco, Honduras (Reptilia, Amphibia). The Herpetological Bulletin 87: $13-24$.

White, F. 1983. The vegetation of Africa. A descriptive memoir to accompany the UNESCO/AETFAT UNSO vegetation map of Africa. Natural Resources Research, 20. UNESCO, Paris.

\section{APPENDIX I}

Voucher specimens from Forêt d'Ambre Special Reserve (including Lac Mahery) and Le Fontenay Nature Park in alphabetical order:

Aglyptodactylus securifer UADBA (FGZC 1378, 1699, 3103), ZSM 2159/2007, 2231/2007, 1633-1635/2008; Alluaudina bellyi ZSM 1626/2008; Blommersia wittei UADBA (FGZC 3137, 3139-3141), ZSM 2229/2007, 1657-1658/2008; Boophis blommersae UADBA (FGZC 1865); Boophis brachychir UADBA (FGZC 1379, 1388, 1392), ZSM 2155-2157/2007, 2227-2228/2007, 2230/2007; 16411642/2008; Boophis septentrionalis ZSM 2158/2007; Boophis tephraeomystax ZSM 1643-1644/2008; Boophis baetkei ZSM 2051/2007, 1638/2008; Boophis sp. nov. aff. brachychir ZSM 1639-1640/2008; Boophis sp. nov. aff. madagascariensis «north» UADBA (FGZC 3130, 3132); Brookesia sp. nov. UADBA (FGZC 1255-1257, 1259, 1261-1262, 1264, 1266-1268, 1700, 1879, 3112), ZSM 2170-2179/2007, 1506/2008; Brookesia stumpffi UADBA (FGZC 1233, 1236-1239, 3113), ZSM 2165-2166/2007; Cophyla sp. nov. ZSM 1659/2008; Furcifer petteri UADBA (FGZC 1224, 1225), ZSM 2160-2161/2007; Geckolepis cf. maculata UADBA (FGZC 1231, 3122), ZSM 2164/2007, 1520/2008; Gephyromantis pseudoasper ZSM 1651/2008; Hemidactylus frenatus ZSM 1533/2008; Lygodactylus sp. ZSM 1542/2008; Madascincus cf. polleni UADBA (FGZC 3123), ZSM 2162/2007, 1558/2008; Mantella viridis ZSM (FGZC 3155); Mantidactylus ambreensis ZSM 1653/2008; Mantidactylus bellyi UADBA (FGZC 1217, 1382, 1384, 3109, 3146-3149, 3159), ZSM 2224-2226/2007, 1652/2008; Mantidactylus aff. betsileanus UADBA (FGZC 1377); Paroedura cf. oviceps ZSM 1527/2008; Paroedura stumpffi UADBA (FGZC 3118), ZSM 2163/2007, 1526/2008; Phelsuma abbotti chekei ZSM (FGZC 3143); Phelsuma lineata dorsivittata UADBA (FGZC 3144); Pseudoxyrhopus cf. ambreensis UADBA (FGZC 3157); Pseudoxyrhopus microps ZSM 1611/2008; Pseudoxyrhopus cf. quinquelineatus ZSM 1608/2008; Rhombophryne sp. nov. UADBA (FGZC 1890, 1891), ZSM 1628-1629/2008; Stenophis granuliceps UADBA (FGZC 1229); Stenophis inopinae ZSM 1603/2008;
Stenophis cf. variabilis ZSM 1605/2008; Stumpffia sp. UADBA (FGZC 1689, 3104-3105, 3152), ZSM 1670/2008; Thamnosophis lateralis UADBA (FGZC 1696, 3150), ZSM 1600/2008; Thamnosophis martae ZSM 2062/2007, 1597/2008; Trachylepis tavaratra UADBA (FGZC 3133, 3135), ZSM 1551/2008; Uroplatus sp. nov. aff. ebenaui ZSM (FGZC 1876, 3116, 3153); Uroplatus giganteus ZSM (FGZC 3165); Uroplatus aff. henkeli UADBA (FGZC 3107), ZSM (FGZC 3117); Uroplatus sikorae UADBA (FGZC 3151); Zonosaurus haraldmeieri UADBA (FGZC 3110), ZSM 1501-1502/2008. 